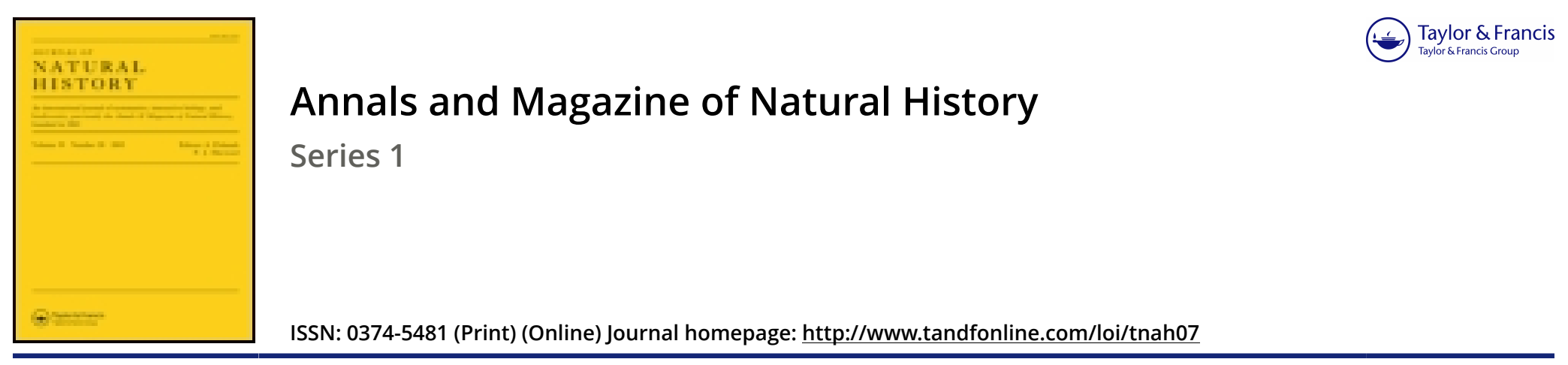

\title{
XXXI.-Florœ Insularum Novœ Zelandiœ Precursor; or a Specimen of the Botany of the Islands of New Zealand
}

\section{Allan Cunningham Esq.}

To cite this article: Allan Cunningham Esq. (1839) XXXI._Florœ Insularum Novœ Zelandiœ Precursor; or a Specimen of the Botany of the Islands of New Zealand, Annals and Magazine of Natural History, 3:17, 244-250, DOI: 10.1080/03745483909443232

To link to this article: http://dx.doi.org/10.1080/03745483909443232

曲 Published online: 04 Dec 2009.

Submit your article to this journal $\pi$

Q View related articles ¿

Citing articles: 1 View citing articles $\widetilde{ }$ 
all the four species drawn up with reference to the above differences.

1. C. lectularius.-Ferrugineo-ochraceus : thorace profundc emarginato, lateribus refexis : abdomine suborbiculnto, apice acuto: antennis articulo tertio quarto longiore.

Long. $2 \frac{1}{2}$ lin. Hab. In domibus.

2. C. columbarius. - Ferrugineo-ochraceus: thorace profunde emarginato, lateribus reflexis : abdomine orbiculato, apice sub. acuto: antennis articulo tertio quarto paulo longiore.

Long. vix $2 \frac{1}{4}$ lin. Hab. In Columbis.

3. C. Hirundinis.-Fusco-ferrugineus: thorace leviter emarginato, lateribus planis: aldomine orato, apice subacuto: antennis brevibus, articulis tertio et quarto subacnualibus.

Long. $1 \frac{3}{4}$ lin. $H a b$. In nidis Hirundinis urbicx.

4. C. Pipistrelli.-Ferrugineo-ochraceus, nitidus: thorace profunde emarginato, lateribus jaulo reflexis: abdomine ovato, postice attenuato : antennis articulo tertio quarto longiore.

Long. 2 lin. Hab. In Vespertilione Pipistrello.

I hare only to add, that the last two species were both taken in Cambridgeshire. Of the C. Pipistrelli I have seen but one specimen.

\section{IREFERENCE TO PLATE Y.}

Fig. 1. C. columbarius. Fig. 2. C. Hirundinis. Fig. 3. C. Pipistrelli. a. One of the antenne. All the figures are highly magnified. The line above each denotes the natural size.

Swafham Bulbeck, April 6, 1839.

XXX1.-Flore Insularum Nova Zelandia Precursor; or a Specimen of the Botany of the Islands of New Zealand. By Alinan Cunimgunan, Esq.

[Continued from p. 116.]

ROSACE正, Juss.

A cosa, l'ahl.

566. A.Sanguisorba. Vahl Enum. i.p.291. DC. Prodr. ii. p.592. Rcem. et Sch. Syst. l'eg. i. p. 208.-A ncistrum Sanguisorba. L. W'illl. Sp. Pl. i. p. 151.-A. diandrum. Forst. Prollr. n. 52. A. lich. Fl. Nov. Zel. p. $3+1$.

New Zealand (Middle Island). Dusky Bay.-1773, G. Forsier. Cook's Strait.-1527, D'Urille. (Northern Island).-1769, Sir Jos. Banks. In dry exposed situations, Bay of Islands, $-1826, A$. Cunningham. 


\section{Rerus, $L$.}

567. $R$. australis, caule glabro teretiusculo, aculeis ramorum secundis recurvis, foliis ternatis quinatisve petiolatis, foliolis ellipticis oratisre extra medium argute serratis, serraturis ncuminatis coriaceis venosis utrinque glabris, floribus axillaribus racemosis dioicis, laciniis calycinis obtusis patentibus, pedunculis ramulisque tomentosis. Forst. Prodr. n. 224. DC. Prodr. ii. p. 556. A. Rich. Fl. Nov. Zel. p. 340.

Tataramora, indigenis.

New Zealand (Northern Island).-1769, Sir Jos. Banks. Margins of forests, Wangaroa.-1826, A. Cumningluam. (Middle Island).-1773, $G$. Forster.

508. R. Schmidelioides, canle glabro tereti, aculeis ramorum brevissimis sparsis revurvis, foliis ternatis petiolatis, foliolis ovalibus lato-ellipticisve coriaceis rugosis venosis extra medium serratis acutis basi rotundatis subcordatis supra viridibus levibus, subtus pedunculis ramulisque ferrugineotomentosis, racemis axillaribus conferti floris brevibus paniculatis, floribus dioicis, calycibus obtusis lanatis.

New Zealand (Northern Island). Forests at Wangaroa and Bay of Islands._-1826, A. Canninghan.

Obs. Habitus procedentis, sed differt foliolis omnino ternatis rugosis venosis subtus (discoloribus) valde ferrugineo-tomentosis, racemoque multo breviore.

569. R. cissoides; caule glabro tereti ramoque inermi, foliis ternatis quinatisve elliptico-lanccolatis lanceolatisre petiolatis acuminatis serratis basi rotundatis utrinque læribus, petiolis costisre mediis retrorso-aculeatis, paniculis axillaribus terminalibusve glabriusculis laxis elongatis pendulis, calycinis laciniis ovatis oltusiusculis reflexis tomentosis.

New Zealand (Northern Island). Dense forests of Wangaroa.-1826, $A$. Cumningham.

Obs. Habitus omnino Cissi. Folia presertim quinata longe petiolata, valde nitida et pulcherrime renosa, serraturis acuminatis. Panicula ramosa pedalis.

\section{I.FGUMINOS E, Juss.}

\section{Edwardsia, Salisb.}

570. E.microplyylla, foliolis 33-41, oboratis subrotundis villiosiusculis, carina petalis ellipticis, margine dorsali uncinato. DC. Prodr. ii. p. 97. A. Rich. Fl. Nov. Zel. p. 344.-Sophora microphylla. Ait. Hort. Kew. ed. 1. v. ii. p.42. Jacq. Hort. Schcenb. iii. t. 269. Bot. Mag.t. 1442.

Kowhy or Kongi, indigenis.

New Zealand (Northern Island).-1769, Sir Jos. Banks. Bay of Islands. 1826, A. Cunningham.

571. E. grandiflora, foliolis 17-21 oblongo-linearibus sublanceolatis villosiusculis carina petalis late falcatis. DC. Prodr. ii. $p$. 97 .- Sophora tetraptera. Ait. Hort. Kete. ed. 1. v. ii. p. 43. Curtis Bot. Mag.t.167.

New Zealand (Northern Island),_-1769, Sir Jos. Banks. 
Quid E. microphylla, Wenderoth in Linnca, v. p. 202. ex nova Zelandia, sec. Endl.?

2. Celavtuus, Sol. mss. in Bibl. Bankis.

Calyx late campanulatus subxqualis 5-rientatus. Iexillum acuminatum reflexum, alis parallelis Iongius; Carina scaphiformis, vexillo alisque multo longior, omnino monopetala. Stomina manifeste perigyna, diadelpha, omnia fertilia. Stylus staminibus duplo longior, versus apicem hine leviter barbatus, stigmate simplicissimo. Legumen pedicellatum, coriaceum, acuminatum, ventricosum, polyspermum, intus lanulosum sutura dorsali recta, ventrali convexa. Semina reniformia, funiculis longiusculis afixa.

572. C. puniceus, suffruticosus diffusus glaber, foliolis alternis oblongis subcmarginatis racemis pendulis multifloris, calyce quinquedentato, legnmine glabro. I.indl. in Bot. Reg. 17i5. Sol. mser. in Mus. Brit. A. Cumn. in Mort. Lond. Trans. v. i. (new series) p. 521. t. 22.-Donia punicea. $G$. Don. Syst. of Gard. ii. p. 468.

Kouainguta Kala, indigenis Anglice Parrol's-bill.

New Zealand (Northern Island).-1760, Sir Jos. Banks. Shores of Mercury Bay, 1833, Missionarics.

Suffrutex diffusus ramosus, quinquepedalis, ramis riridibus parum lignosis. Folia 8-juga cum impari. Racemi penduli, multiflori, floribus speciosissinis coccineis. Legumen fere tripollices longum, atro-fuscum, rcuosum. Semina reniformia, fusca, atro-nebulosa. Iindl, loc. cit.

\section{Guilandisa, Juss., $L$.}

573. G. Bonduc, L. DC. Prodr. ii. p. 480. A. Kich. Fl. Nov. Zal. p. 248.-G. Bonducella, L.-Forst. Prodr. n. 185. Rumph. Amb. t. 48. and 19.

New Zenland (Middle Island).-1773, G. Forster.

4. Carsuchiedia, $R$., $B r$.

Caly $x$ cyathiformis quinquedentatus. 'Otarium dispermum. Sligma simplex. Legumen oligospermum (1-3 spermum) replo post lapsum valvularum persistente.

574. C. atstralis. R. Br. in Bot. Reg. 012_-Lotus? arboreus. Forst. Prodr.n.278. Willd.sp. Pl. iii. p. 1392. A. Rich. Fl. Nov. Zcl.p. 315. DC. Prodr. ii. p. 214.-Bossiaza Scolopendrea. A. Rich. Fl. Nov. Zel.p. 345. non Brownii atque excl. syn. Andreusii Ventenatisque.-Genista compressa. Sol. ms. in Bibl. Banks.

New Zcaland (Northern Island). On the east side.-1709, Sir Jos. Banks. Frequent in dry woods and open sandy shores among underwood. -1S26, A. Cunninghum.-(Middle Island). Dusky Bay.-1773, G. Forster.

Frutex ramosissimus (sexpedalis) sub statu florescentix sæpius aphyllus. Caulis ranique primarii teretes, tenuiores $v$ plano-compressi v. ancipitcs, stipulis minutis alternatim dentati. Folia e dentibus ramorum fruticis junioris tcrnata v. pinnata (foliolis $3-7$, obcordatis). Racemi simplicissimi e denticulis ramonum. Flores parri albo-purpurei. Petala longitudine 
subxqualia, vexillum lamina latiore quam longiore basi absque callis auriculisve, carina obtusa. Fïlamenta 1-9 fida. Ovarium lineare, 5-6-spermum. Stylus subalatus. Stigma obtusum, imberbe. Semina reniformia, sinu clauso, umbilico nudo. $R . B r$.

This very remarkable plant seems to have been but imperfectly understood until Mr. Brown ably defined the true structure of its pod. Forster, with an expression of doubt, referred it to Lotus, in which genus it was retained by Willdenow, notwithstanding that he appears to have been acquainted with its fruit; and by DeCandolle in the 2nd rol. of his 'Prodromus,' which appeared in 1825, who could not have been aware of its having been erected into a new genus by Mr. Brown; and from the MSS. of that eminent botanist, published in the 'Bot. Reg.' in September of that year. But the blunders of M. Ach. Richard, respecting this very curious plant which had been living in the English gardens antecedent to the publication of his 'Essai d'une Flore de la Nouv. Zélande' in 1832, (and one might have supposed it would at that time have got into the Paris gardens from us) appear wholly incxplicable. Apparently altogether ignorant of Mr. Brown's name, and evidently without an idea of what Forster meant by Lotus? arboreus, he not only inserts this latter in his work from Forster's MISS, at some length, but on finding specimens in fruit of the Carmichaelia in the collections formed during the voyage of the Astrolalue by Capt. D'Urville (who had gathered them in the Bay of Islands in 1827), he confounds them with Bassicea Scolopendria, a common Port Jnckson plant; and thus our genus appears, in his volume on the Botany of New Zealand, under two names, viz. the above one of Bassiaa, and that of Lotus.

RHAMNEE, R. $R r$.

1. Canpoderus, Forst. Gen.t.17.

575. C. serratus. Forst. Prodr, n. 11. Char. Gen. t. 1\%. DC. Prodr. ii. p. 29. A. Rich. Fl. Nov. Zel. p. 360.

Piri-piri-uater ab incolis dicitur.

New Zealand (Middle Island).-1773, G. Forster. (Northern Islaud.) On the alluvial banks of rivers, occasionally in salt-water marshes, Wangaroa, \&c. bearing fruit in December.-1826, $A$. Cunningham.

Arbuscula 10-20 pedalis, ramosa, ramis foljusis sparsis divaricatisve, foliorum casu tuberculatis. Folia alterna, ovalia, oblonga, acuta, petiolata, glanduloso-serrata, superne puberula, subtus discolora, glabra, reticulata. Racemi axillares, terminalesve corymbosi. Calyx turbinatus ovario adnatus, limbo 5-partito, laciniis linearibus deciduis. Corolla 5-petala, petalis albis, astivatione valvatis, calycis limbo duplo longioribus. Slamina 5, filamentis subulatis cum petalis alternantibus. Stylus simplex, erectus, 
staminibus longior. Fruclus coriaceus, subglobosus, quasi zona cinctus ex margine calycis adnato, 5-locularis. Seraina plura, angulata rugulosa.

\section{Pexwantia, Forst., Gen. 67.}

Calycis sepala 5, lanceolata, acuta, xstiratione imbricata, in anthesi patentiscima. Stamina 5, lypogyna, sepalis alterna; filamentis liberis, antheris introrsus bilocularibus, dorso affixis. Otaritum sessile, oratooblongum, 3 loculare, loculis biorulatis, ovulis ex apice loculi pendulis. Stigna sessile, discoideum, obsolete 3-lobum. Fructus drupaceus, monospermus, semine inverso. Encll.

576. P. corymbosa. Forst. Prodr. n. 379. Willd. Sp. Pl. iv. p. 1122. Endl. Prodr. Fl. Norf. p. 80. Rem. et Sch. Syst. Veg. v. 5.p. 560. A. Rich. Fl. Nov. Zel. p. 368. Icon. Ferd. Bauer, illustr. Pl. Norf. Ins. t. 165.

New Zealand (Middle Island).-1773, G. Forster.

Arbor 40-pedalis, et infra cortice albo. Rami teretes, albo-punctati, fistulosi. Folia alterna, petiolata, elliptico-oblonga v. obovata, integerrima (vel extra medium serrata) emarginata, venosa, glabra. Flores hermaphroditi, pentandri, paucissimis abortu masculis intermixtis, corymbosi. Corymbi cymosi, 4-pollicares, in ramis ramulisque terminales. Otarium 3 loculare, loculis biovulatis, ovulis pendulis superpositis. Drupa atro-purpurea stigmate coronata, semine unico inverso foeta.

\section{Pomndennis, Labill. \\ Flores petaliferi.}

577. P. Kumeralıo, cymis densifloris umbellato-paniculatis, foliis ellipticis coriaceis valde obtusis super glabris subrugulosis margine tenuiter crenulatis integrisve subtus alte costatis ramulisque albo-tomentosis.

Kumeraho nom. veruaculum. R. Cunningham.

New Zealand (Northern Island). Banks of the Keri-Keri river, \&c., Bay of Islands.-1826, A. Cunninghain.-1833, R. Cunningluam.

Obs. Valde aftinis $P$. elliplica quac differt foliis prescrtim acutioribus, panicula multo minore et laxiore, foribusve perquam minus confertis.

The flowering of this shrub, which takes place in the month of September, the spring of New Zealand, is the signal for the natives to plant their Koomeras or sweet potatocs; hence doubtless originates the name by which they call this plant in the present day.

\section{-* Flores apetali.}

578. $P$. ericifolia, foliis linearibus pubescenti-scabris marginibus conduplicato-rcrolutis subtus cinereo-lirsutissimis, cymis parvifloris axillaribus folio vix longioribus, stipulis subulatis ramisque oblongis. Hooker, Journ. Dot. i.p. 257.

Tuturnai incolarum.

New Zealand (Northern Island). On hills among fern, Bay of Islands. -1826, A. Cunningham. 
The above character accords so fully with the plant from New Zealand, as to leave no doubt of its identity with that from Van Diemen's Land, recently described by Sir TWm. J. Hooker in the work above quoted.

Fruticulus incanus, erectus, ramosissimus. Rami stricti, numerosi. Folic linearia, obtusa, petiolata, 3-4 lineas longa, supra convexa, margine valde revoluta. Flores parvi apctali cymosi, pedunculati, folia subxquantia. I'erianthium 5 -fidum, laciniis oratis acutis. Stamina 5 , inclusa, segmentis perianthii alterna. Stylus apice trifidus staminum longitudine. Stigmata tria.

\section{Gertus noum Rhamneis affine, -}

Coroxia.

Flores dioici. Mas. - Fom. Calycis tubus ovario adherens limbo 5fido persistente, per æestivationem valvato. Petala 5, lanceolata, lobis calycis alterna, decidua. Discus carnosus, glandulosus, epigynus. Stylus 1. Stigna capitatum lobatum. . Otarizm inferum biloculare, loculis 1-ovulatis pendulis. Drupa 2-locularis, loculis 1-spermis.

579. C. Buddleioides.

Korokia-taranga, appellatio incolarum est. R. Cunn.

Nerr Zealand (Northern Island). Margins of woods, on the shores of the

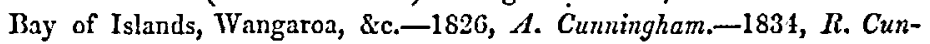
ningham.

Caulis fruticosus, 10 pedalis, ramis ramulisque strictis albo-tomentosis instar Buddleice. Folia alterna, lanceolata, acuta, petiolata, coriacea, supra plerumque glabra, valde lucida, subtus dense albo-lanata. Flores parvi, subpaniculati, paniculis brevibus sæpius axillaribus v. terminalibus cano-pilosis. Corolla petala alba, oblongo-lanceolata, reflexa, segmentis calycis ter longiora, extus incano-villosa, intus glabra. Drupa sphærica, pisi magnitudine (epicarpio fragili, nigro, nitido) apice umbilicato villosa.

Nomen hujus generis ad nomen vernaculum refert.

\section{Genus novum Ordinis manifeste intus \\ Brexiaceas el Celastrineas. \\ IXERBA.}

Caly $x$ inferus, 5-phyllus, persistens, xstivatione imbricata. Petala 5, membranacea, unguiculata, disco hypogyno inserta, decidua, fere astivatione imbricata. Stamina 5, hypogyna, petalis alterna. Anthera ovatx acuminatx, adnatre, biloculares, longitudinaliter dehiscentes. Discus hypogynus, carnosus, 5-lobatus, lobis inter bases staminum retusis integris. Stylus 1 , angulatus, continuus, versus apicem attenuatus. Stigma simplex. Ovarium superum 5-lobum, 5-loculare, loculis 2-ovulatis, ovulis collateralibus suspensis. Fructus nondum vidi.

Nomen Brexice anagramma est, cui generi nostra planta certe maxime affinis.

580. I. Brexioides.

New Zealand (Northern Island). $A$ tree on the skirts of woods at Wangaroa, Nov. 1828. A. Cunningham.

Ann. Nat.Hist. Vol.3. No. 17. June 1839. T 
Arbor elegans sempervirens, viginti pedalis et infra; ramis tcretibus glabris, cortice rugoso. Folia ( -5 uncialia) alterna, petiolata, exstipulata, ad summitatem ramulorum sxpe verticillato-conferta, elongato-lanceolata, acuminata, obtusiuscula, coriacea remote calloso-serrata, utrinque glabra, superne nitida, subtus pallidiora. Flores albi, terminales, corymbosi, pedunculis (uncialibus) plerumque trichotomis.

One of the most remarkable plants of New'Zealand, where, horrever, it is of very rare occurrence, and in affinity approaching nearer to Brexia of M. da Petit Thouars than to any other published genus. With it our plant accords in the acstivation and forms of the calyx and petals, in its hypogynous stamens and the figure of the anthers, and in its superior pentagonal quinquelocular ovarium with a disk at its base. In the form of these lattcr, however, our genus differs essentially; having neither, in the one, an indefinite number of ovules attached in two rows to placentic in the axis, nor in the other the toothed or fringed lobes hetween the bases of the stamens, as botanists have described the genus of M. du Petit Thouars. The matured fruit of Ixerba has not yet been examined, so that the structure of the seeds remains to be ascertained. Its nearest affinity appears with Celastrinca, with which it agrees in the estivation of the floral cuvelopes, the number of the stamens, and their alternating with the petals, but differing in the insertion of the stamens; these, in that family being perigynous, and the ovules, for the most part, ascending from the axis of the ovarium.

[To be continued.]

\section{XXXII.-Information respecting Botanical Travellers.}

Mr. Gardner's Journeys in Brazil.

Taz following extracts of letters lately received from Mr. Gardner cannot fail to give pleasure to those who take an interest in his travels and collections, which promise to throw great light on the history of the vegetable productions of a very extensive and hitherto little explored region of tropical South America.-Enir.

Villa do Icó, Sertão of the Province of Seiró, August 25, 1838.

About the middle of last month I did myself the pleasure of writing to you from Pernambuco, stating that it was my intention to pass into the interior from Aracaty, a sea-port in this province, and pro. bably to try to reach the mountains to the west of the province of 